\title{
Co-infection and risk factors of tuberculosis in a Mexican $\mathrm{HIV}^{+}$population
}

\author{
Coinfecção e fatores de risco de tuberculose em uma população Mexicana com $\mathrm{HIV}^{+}$
}

\author{
Roberto Zenteno-Cuevas ${ }^{1}{ }^{*}$,Evangelina Montes-Villaseñor ${ }^{1,2}$, Jaime Morales-Romero ${ }^{1}$, Gastón Coronel-Martín \\ del Campo ${ }^{2}$ and Betzaida Cuevas ${ }^{1}$
}

\begin{abstract}
Introduction: The situation of tuberculosis $(\mathrm{TB})$ is being modified by the human immunodeficiency virus (HIV), which is increasing the occurrence of new cases and the generation of drug resistant strains, affecting not only the people infected with HIV, but also their close contacts and the general population, conforming a serious public health concern. However, the magnitudes of the factors associated to this co-infection differ considerably in relation to the population groups and geographical areas. Methods: In order to evaluate the prevalence and risk factors for the co-infection of tuberculosis (TB) in a population with human immunodeficiency virus $\left(\mathrm{HIV}^{+}\right)$in the Southeast of Mexico, we made the analysis of clinical and epidemiological variables and the diagnosis of tuberculosis by isolation of mycobacteria from respiratory samples. Results: From the $147 \mathrm{HIV}^{+}$individuals analyzed, 12 were culture positive; this shows a prevalence of $8 \%$ for the co-infection. The only variable found with statistical significance for the co-infection was the number of CD4-T $<200$ cells $/ \mathrm{mm}^{3}$, OR 13 (95\%, CI 2-106 vs 12-109). Conclusions: To our knowledge this is the first report describing the factors associated with tuberculosis co-infection with HIV in a population from Southern Mexico. The low number of CD4 T-cells was the only variable associated with the TB coinfection and the rest of the variables provide scenarios that require specific and particular interventions for this population group.
\end{abstract}

Keywords: Tuberculosis. HIV. Risk factors. Co-infection.

\section{RESUMO}

Introdução: A situação da tuberculose (TB) foi modificada pelo vírus da imunodeficiência humana (HIV). Com isso, aumentou-se a ocorrência de novos casos de TB e a geração de cepas resistentes à droga, afetando não só as pessoas infectadas com HIV, mas também seus contatos próximos e da população em geral, gerando um sério problema de saúde pública. No entanto, a magnitude dos fatores associados à esta coinfecção diferem consideravelmente em relação aos grupos populacionais e áreas geográficas. Métodos: Para avaliar a prevalência da comorbilidade e fatores de risco da coinfecção de tuberculose (TB) em uma população com o vírus da imunodeficiência humana $\left(\mathrm{VIH}^{+}\right)$no sudeste do México, nós fizemos a análise das variáveis clínicas e epidemiológicas e de isolamento da micobactérias através de cultura de amostras respiratórias. Resultados: A partir de 147 indivíduos $\mathrm{HIV}^{+}$analisados, 12 foram positivos na cultura, o que mostra uma prevalência de $8 \%$ para a coinfecção. A única variável com significância estatística encontrada para a coinfecção foi o número de células CD4-T<200 células $/ \mathrm{mm}^{3}$, OR 13 (95\%, CI 2-106 vs 12-109). Conclusões: Ao nosso conhecimento este é o primeiro relatório que descreve os fatores associados à coinfecção de tuberculose com HIV em uma população do sudeste do Mexico. O baixo número de células $\mathrm{T} \mathrm{CD}^{+}$foi à única variável associada com a coinfecção por TB no resto das variáveis, proporcionando situações que exigem intervenções específicas e particulares para este grupo populacional.

Palavras-chaves: Tuberculose. HIV. Fatores de risco. Coinfecção.

1. Instituto de Saúde Pública, Universidade Veracruzana, Xalapa, Veracruz, México. 2. Centros Ambulatorios de Prevenção e Atenção em SIDA e ITS, Hospital Civil L. F. Nachón, Xalapa, Veracruz, México.

Address to: Dr. Roberto Zenteno-Cuevas. Instituto de Salud Publica de La Universidad Veracruzana. Av. Luis Castelazo Ayala s/n, Apto 57, Col. Industrial Animas, 91190 Xalapa, Veracruz, México.

Phone: 52228 841-8933; Fax: 52228 841-8935

e-mail: robzencue@gmail.com.mx

Received in 02/08/2010

Accepted in 20/01/2011

\section{INTRODUCTION}

According to the World Health Organization (WHO) in 2007, out of a total of 9.3 million incident cases of tuberculosis (TB), 1.4 million cases and 480,000 deaths were related to HIV/ AIDS coinfection ${ }^{1}$. The epidemiology of TB is being modified by the human immunodeficiency virus (HIV), which is causing an increase in the occurrence of new cases and the generation of drug resistant strains, affecting not only individuals infected with HIV, but also their close contacts and the general population, a situation that poses a serious public health concern ${ }^{1-4}$.

The epidemiological and clinical characteristics of $\mathrm{TB}$ in the $\mathrm{HIV}^{+}$population are markedly different to those of TB alone ${ }^{3}$. The risk of acquiring TB increases by $10 \%$ and the speed of progression increases considerably. Malnutrition, domestic overcrowding and low number of CD4 T cells are factors frequently associated with the acquisition of $\mathrm{TB}$ in $\mathrm{HIV}^{+}$individuals; however, the magnitude of individual factors varies considerably according to population groups and geographical areas ${ }^{3-6}$.

The annual incidence rates for TB and HIV in Mexico are 14 and 116 per 100,000 habitants, respectively. The State of Veracruz is located in southeastern Mexico, has 7 million habitants and annual incidences for TB and HIV of 23 and 162 per 100,000 habitants, respectively ${ }^{7,8}$; however, the prevalence of $\mathrm{TB}$ in $\mathrm{HIV}^{+}$individuals and the factors associated with coinfection are poorly understood. The aims of this study were to establish the prevalence of coinfection and to determine the risk factors for $\mathrm{TB}$ acquisition in an $\mathrm{HIV}^{+}$population from Veracruz, Mexico.

\section{METHODS}

\section{Population, diagnostic procedure and} determination of risk factors

The study comprised a population of 240 individuals with a diagnosis of HIV confirmed by western blot. Only individuals older than 15 years of age and who consented to participation in the study 
were included. All the patients were receiving retroviral treatment and were registered at the Care Center for Patients with Sexually Transmitted Diseases and Acquired Immune Deficiency Syndrome (AIDS), from Xalapa, Veracruz, Mexico.

Sterile containers were given to each patient so that they could collect an early morning sputum sample at home for three consecutive days. When the patients returned to the clinic with their samples, a survey was conducted to identify the risk factors. Additional questions, regardless of knowledge of the main symptoms of $\mathrm{TB}$, were put to the patients.

The samples were decontaminated by the modified Petroff's method ${ }^{9}$ and cultured in Lowenstein Jensen medium slants at $37^{\circ} \mathrm{C}$. The slants were examined twice weekly for the first 2 weeks and once weekly thereafter. Cultures were considered negative when no growth was observed after 8 weeks.

\section{Statistical analysis}

The questionnaire and culture results for each patient were entered into a database and statistical analyses were performed using Epi-Info ${ }^{\mathrm{TM}}$ version 6 (CDC, USA) and SPSS 7.0 for Windows (SPSS, Inc., USA). Bivariate analyses were performed by using the Chi square $\left(X^{2}\right)$ tests and estimation of odds ratios (OR) with $95 \%$ confidence intervals $(95 \% \mathrm{CI})$. The results were considered to be significant when $\mathrm{p} \leq 0.05$. Multivariate logistic regression models were constructed to identify the factors independently associated with $\mathrm{TB}$ infection among the $\mathrm{HIV}^{+}$population. The dependent variable was TB infection and the covariables were: age $\leq 40$ yearsold, sex, salary, incidence of alcoholism and a cell count of $<200$ $\mathrm{CD}^{+} \mathrm{T}$ cells $/ \mathrm{mm}^{3}$. Adjusted OR with $95 \% \mathrm{CI}$ for the independent variables was calculated for the final model.

\section{Ethical considerations}

Ethical considerations were strictly observed; all the information collected was confidential and written consent was obtained from each patient.

\section{RESULTS}

Between February and July 2007, questionnaire results and sputum clinical samples from 147 (61\%) of the patients were collected. The remainder of the population, 93 (39\%) individuals, declined to participate. Baseline information showed that 88 (60\%) individuals were male and $59(40 \%)$ were female. The mean age was 35 years-old and 104 (70\%) were between $15-40$ years-old. The mean number of years with a positive diagnosis of HIV was 2.4, with a standard deviation of 4 years. Ninety-seven $(66 \%)$ individuals were single and 85 (57\%) had received more than basic formal education (> 6 years of schooling). A monthly salary of more than US\$280 was reported by 105 (71\%) individuals, 89 (69\%) lived in an urban area, while 60 (40\%) customarily slept with less than 3 people in the same room. Tobacco and alcohol consumption was observed in 30 (20\%) and 37 (25\%) individuals respectively. The CD4 T cell load of $<200$ cells $/ \mathrm{mm}^{3}$ was observed in $71(48 \%)$ of individuals and a body mass index of $\leq 18.5 \mathrm{~kg} / \mathrm{m}^{2}$ was recorded in $66(44 \%)$ individuals. Only $1(0.6 \%)$ person reported previous TB diagnosis and prophylactic treatment. Contact with a person with TB in the preceding year was reported by 39 (26\%) individuals, while 129 (87\%) were able to recognize the main symptoms of TB.

Analysis of diagnosis by culture showed that only 12 patients were TB positive. Based on this information, TB prevalence in this $\mathrm{HIV}^{+}$population group was $8 \%$.

Despite the fact that no clinical signs of TB were observed in these $\mathrm{TB}_{-} \mathrm{HIV}^{+}$individuals, they showed some common characteristics: 8 were male and single, all were less than 35 years-old, 9 slept in the same room with more than 3 people, 6 had low financial income, 11 presented a number of CD $4 \mathrm{~T}$ cells $<200$ cells $/ \mathrm{mm}^{3}$ and 7 had a body mass index less than $185 \mathrm{~kg} / \mathrm{m}^{2}$. Four individuals reported previous contact with a TB infected individual in the preceding year, while only two were unable to recognize the main symptoms of TB (Table 1).

TABLE 1 - Host-related variables for tuberculosis in HIV+ patients from Veracruz, México.

\begin{tabular}{|c|c|c|c|c|c|}
\hline \multirow[b]{3}{*}{ Variable } & \multicolumn{2}{|c|}{ Patients diagnosed } & \multirow[b]{3}{*}{ Odds ratio } & \multirow[b]{3}{*}{ Confidence intervaI (95\%) } & \multirow[b]{3}{*}{ P value } \\
\hline & positive & negative & & & \\
\hline & $\mathrm{n}=12$ & $\mathrm{n}=135$ & & & \\
\hline Gender (male) & 8 & 80 & 1.3 & $0.3-57$ & 0.61 \\
\hline Marital status (single) & 8 & 89 & 1.0 & $0.26-4.3$ & 0.98 \\
\hline Education ( $\leq 6$ years $)$ & 7 & 55 & 2.0 & $0.5-7.8$ & 0.23 \\
\hline Domestic overcrowding ( $\geq 3$ people sleeping in one room) & 9 & 78 & 0.4 & $0.1-1.9$ & 0.24 \\
\hline Rural residence & 5 & 53 & 1.1 & $0.2-4.1$ & 0.52 \\
\hline Alcohol consumption & 4 & 33 & 1.5 & $0.3-6.1$ & 0.49 \\
\hline Tobacco consumption & 1 & 29 & 0.3 & $0.0-2.6$ & 0.27 \\
\hline Monthly salary $\leq 280$ US $\$$ & 6 & 36 & 2.7 & $0.7-10.4$ & 0.08 \\
\hline Number of CD $4-\mathrm{T}$ cell $\leq 200$ cells $/ \mathrm{mm}^{3}$ & 11 & 60 & 13.7 & $1.7-292$ & $<0.01$ \\
\hline Body mass index $\leq 185 \mathrm{~kg} / \mathrm{m}^{2}$ & 7 & 59 & 1.8 & $0.4-6.9$ & 0.32 \\
\hline Contact with a person with TB & 4 & 35 & 1.4 & $0.3-5.6$ & 0.62 \\
\hline No recognition of TB symptoms & 2 & 16 & 1.4 & $0.0-8.3$ & 0.64 \\
\hline
\end{tabular}


TABLE 2 - Comparison of risk factors for tuberculosis, diagnosed by culture in an HIV+ population from Veracruz, Mexico.

\begin{tabular}{|c|c|c|c|c|c|c|}
\hline \multirow[b]{2}{*}{ Predictive factor } & \multicolumn{3}{|c|}{ Unadjusted model } & \multicolumn{3}{|c|}{ Adjusted model* } \\
\hline & $\mathrm{OR}^{* *}$ & CI $95 \%$ & $\mathrm{p}$ & $\mathrm{OR}^{* *}$ & CI $95 \%$ & $\mathrm{p}$ \\
\hline Age $(<40$ year $)$ & 0.79 & $0.2-3.1$ & 0.73 & - & - & 0.78 \\
\hline Gender (male) & 1.0 & $0.3-4.2$ & 0.90 & - & - & 0.76 \\
\hline Salary $(\leq$ US\$280) & 2.9 & $0.8-11.0$ & 0.11 & - & - & 0.14 \\
\hline Alcoholism & 1.7 & $0.4-7.6$ & 0.46 & - & - & 0.64 \\
\hline $\mathrm{CD} 4-\mathrm{T}^{\ddagger}<200$ cells $/ \mathrm{mm}^{3}$ & 13.0 & $2.0-106$ & 0.02 & $13.0^{* * *}$ & $2-109$ & 0.01 \\
\hline
\end{tabular}

The only factor associated with TB infection was the number of lymphocyte $\mathrm{CD}^{+} \mathrm{T}$ cells $<200$ cells $/ \mathrm{mm}^{3}, \mathrm{OR}=13.7$ (95\%CI 1.7-292) (Table 1) and according to the multivariate analyses, this was the only significant risk factor for TB in the crude versus adjusted model OR $=13$ vs OR $=13$ (95\%CI 2-106 vs 2-109) (Table 2).

\section{DISCUSSION}

Several of the variables identified in the $\mathrm{HIV}^{+}$population in this study, such as the high number of patients below 40 years of age, low number of $\mathrm{CD}^{+} \mathrm{T}$ cells, body mass index and alcohol and tobacco consumption, were similar to those verified in studies from South Africa $^{10}$, Brazil $^{11}$ and Kenya ${ }^{12}$.

The prevalence for coinfection in this population was $8 \%$, close to the $9 \%$ reported in South Africa ${ }^{10}$ and to the global estimate of $10 \%$ by the $\mathrm{WHO}^{1,2}$. This is higher compared to the national (5\%) and Latin American (1.3\%) prevalences, ${ }^{7,8}$, but lower compared to reports from other states from northern and central Mexico, such as Baja California (18\%) and City of Mexico (13\%) $)^{13,14}$.

To our knowledge, this is the first study related to the prevalence and identification of risk factors for TB coinfection in a $\mathrm{HIV}^{+}$ population from southern Mexico. The results showed that a $\mathrm{CD}^{+} \mathrm{T}$ cell count $<200$ cells $/ \mathrm{mm}^{3}$ was the only variable associated with the acquisition of TB. However, several of the characteristics analyzed in the $\mathrm{HIV}^{+}$population, such as sex, marital status, education, domestic overcrowding and body mass index, highlight particular tendencies within this population and should be taken into account if further interventions against TB are to be conducted.

In addition to diagnosis by culture, acid fast staining by Ziel Nielsen (AFS-ZN) was applied to the respiratory samples and an in-house PCR procedure, developed by our group ${ }^{15}$. The results showed prevalences for $\mathrm{TB}-\mathrm{HIV}^{+}$coinfection of $36 \%$ for AFS-ZN and $50 \%$ for PCR; however, these results were confirmed by the culture test in only 5 (41\%) and 11 (90\%) individuals, respectively. This over-diagnosis by the AFS-ZN diagnostic test is a phenomenon commonly reported in the literature ${ }^{4,6}$, when respiratory samples from $\mathrm{HIV}^{+}$individuals with a low number of CD4-T cells are analyzed, and is associated with the presence of acid-alcohol resistant microorganisms, such as Actinomyces or Nocardia ${ }^{16}$.

Nonclinical signs of TB were observed in the $\mathrm{TB}^{-\mathrm{HIV}^{+}}$ population studied, an aspect generally explained in terms of alterations in the normal host immune response that, among other things, markedly reduce the formation of cavitations in the lung and decrease the transference of bacilli into respiratory secretions, affecting the presentation of clinical signs of the disease and therefore the sensitivity and specificity of traditional probes ${ }^{2,4,6}$. This reveals the possibility of the existence of more TB cases, which may have gone undiagnosed by the culture procedure. The main limitations of the present study were that the experimental design did not consider the clinical follow-up of the patients with a negative diagnosis by culture and examination for other coinfections in the positive cases. Such information could help to confirm or invalidate the TB prevalences determined by AFS-ZN and the in-house PCR.

In conclusion, within the $\mathrm{HIV}^{+}$population analyzed in the present study, the prevalence of TB comorbidity was $8 \%$ and a CD $4^{+}$ $\mathrm{T}$ cell count $<200$ cells $/ \mathrm{mm}^{3}$ was the only associated risk factor. More attention needs to be given to these individuals in order to increase the number of CD4 $\mathrm{T}$ cells and to improve the immune response against TB. It is also necessary to include more rapid, specific and sensitive diagnostic procedures ${ }^{17}$, in order to detect reactivation or new tuberculosis infections in the early stages of disease. This action will have important implications on the surveillance of HIV positivity in individuals from countries like Mexico, where TB is endemic.

\section{CONFLICT OF INTEREST}

The authors declare that there is no conflict of interest.

\section{FINANCIAL SUPPORT}

This work was supported by the grants CONACyT-SALUD 2005.02-14380 and POA-ISP-UV 2007-2008. EMV and B. Cuevas were CONACyT fellowship.

\section{REFERENCES}

1. World Health Organization. Global tuberculosis control 2009. Epidemiology, strategy, financing. [cited 2009 Nov 13]. Available from: http://www.who.int/ tb/publications/global_report/2009/pdf/full_report.pdf

2. Mendelson M. Diagnosis tuberculosis in HIV-infected patients: challenges and future prospects. Brit Med Bull 2007; 81:149-165.

3. Corbett EL, Watt CJ, Walker N. The growing burden of tuberculosis. Global trends and interactions with HIV epidemic. Arch Intern Med 2003; 163:1009-1021.

4. Aaron L, Saadoun D, Calatroni I, Launay O, Mémain N, Vincent V, et al. Tuberculosis in HIV-infected patients: a comprehensive review. Clin Microbiol Infect 2004; 10:388-398.

5. Godfrey-Faussett P, Ayles H. Can we control tuberculosis in high HIV prevalence settings? Tuberculosis (Edinb) 2003; 83:68-76.

6. Sharma SK, Mohan A, Kadhiravan T. HIV-TB co-infection: Epidemiology, diagnosis and management. Indian J Med Res 2005; 121:550-567. 
7. Servicios de salud de Veracruz. Action program 2007. Situation of TB in Mexico. [cited 2009 Nov 13]. Available from: http://sesver.ssaver.gob.mx/portal/ page?_pageid=693,6992673\&_dad=portal\&_schema=PORTAL/.

8. Pan-American Health Organization. Plan Regional de Tuberculosis, 2006-2015. [cited 2009 Nov 13]. Available from: http://www.paho.org/Spanish/AD/DPC/ CD/tb-reg-plan-2006-15.pdf/.

9. Petroff SA. A new and rapid method for the isolation and cultivation of tubercle bacilli directly from the sputum and feces. J Exp Med 1915; 21:38-42.

10. Wood R, Middelkoop K, Myer L, Grant A, Whitelaw A, Lawn S, et al Undiagnosed tuberculosis in a community with high HIV prevalence. Am J Resp Crit Care 2007; 175:87-93

11. Ramos I, Militao M, Leite A, Lacerda H. Characteristics of pulmonary tuberculosis in HIV seropositive and seronegative patients in a Northeastern region of Brazil. Rev Soc Bras Med Trop 2004; 37:46-50.

12. Kivihya-Ndugga L, van CleeffM, KimwomiJ, Githui W, Oskam L, Schuitema A, et al Comparison of PCR with the routine procedure for diagnosis of tuberculosis in a population with high prevalences of tuberculosis and human immunodeficiency virus. J Clin Microbiol 2004; 42:1012-1015.

13. Viani RM, Lopez G, Chacón-Cruz E, Hubbard P, Spector SA. Poor outcome is associated with delayed tuberculosis diagnosis in HIV-infected children in Baja California, Mexico. Int J Tub Lung Dis 2008; 12:411-416.

14. Cicero R, Olivera H, Hernández-Solis A, Ramírez-Casanova E, Escobar-Gutiérrez A. Frequency of Mycobacterium bovis as an etiologic agent in extrapulmonary tuberculosis in HIV-positive and -negative Mexican patients. Eur J Clin Microbiol Infect Dis 2009; 28:455-460.

15. Zenteno R, González L, Cuéllar A, Parissi A, Fuentes J. Detection of Mycobacteria in sputum samples by the amplification of the marker, rDNA16S, by the polymerase chain reaction. Bioquimia 2008; 33:4-9.

16. Rasheed MU, Belay G. Nocardiosis in HIV seropositive clinically suspected pulmonary tuberculosis patients. Trop Doct 2008; 38:34-35

17. Cuevas B, Zenteno-Cuevas R. Drug resistant tuberculosis: molecular mechanisms and diagnostic methods. Enferm Infec Microbiol Clin 2010; 28:621-628. 